\title{
Effective Use of Plant-Derived Urease in the Field of Geoenvironmental/ Geotechnical Engineering
}

Dilrukshi RAN ${ }^{*}$ and Satoru Kawasaki

${ }^{1}$ Graduate School of Engineering, Hokkaido University, Kita 13, Nishi 8, Kita-ku, Sapporo, Hokkaido 060-8628, Japan

${ }^{2}$ Faculty of Engineering, Hokkaido University, Kita 13, Nishi 8, Kita-ku, Sapporo, Hokkaido 060-8628, Japan

\begin{abstract}
Geotechnical and geo-environmental engineering applications currently being explored through bio mineralization process include cementation of sands to improve mechanical properties and hence, to enhance bearing capacity and liquefaction resistance, sequestration of carbon, soil erosion control via surficial stabilization, groundwater flow control and remediation of soil and groundwater impacted by metals and radionuclides. Bio mediated system broadly refers to a chemical reaction series that are managed and controlled through biological activities and byproducts resulting from those reactions alter the properties of material in the system. Bio mediated methods such as microbial induced calcite precipitation (MICP), biofilm formation, biogas generation and biopolymers have been developed by injecting or stimulating microbes. MICP is the most widely explored method. Microbes having urease activity enhance the hydrolysis of urea and it helps to control the $\mathrm{pH}$ and to precipitate carbonate. Although it is a widely explored bio mediated method it has some disadvantages.
\end{abstract}

The plant-derived urease may offer many benefits over microbial urease to induce carbonate cementation. Therefore, it is advantageous to explore the knowledge regarding such a technique as an eco-friendly method for different applications in the fields of geoenvironmental/geotechnical Engineering. The main objective of this paper is to provide an overview of the importance of plant-derived urease for different applications in the fields of geoenvironmental/ geotechnical engineering. The information presented in this paper may be important for biotechnologists/geoengineers to have wide ranging updates on the current situation.

Keywords: Bio mineralization; Cementation; Geotechnical engineering; Geoenvironmental engineering; Plant-derived urease

\section{Introduction}

Geotechnical engineering studies the strength and deformation of soil for successful designs of foundations and environmental engineering studies contaminants within the surrounding environment. Successful planning to improve the soil characteristics by different ground improvement techniques by assuring minimum damage to the environment, and cleaning the contaminated soil, water and air by various treatment methods are being implemented worldwide via sustainability concepts. Current ground improvement techniques in practice include grouting via cement, chemical, compaction, fracture and jet, micro piles, jacked piers, driven piers, ground anchors, shoring, soil nailing, vibro compaction, concrete columns, piers, etc. [1]. Voids of soil are filled with fluid chemical grouts during the chemical grouting. The most common chemical grouts are sodium silicate, acrylate, lignin, urethane, and resin grouts. All of these synthetic chemical grouts are hazardous and/or toxic and hence, ground water pollution may be a potential problem. On the other hand, the cement-based concrete system is not preferred due to the high costs of cement and the high amount of $\mathrm{CO}_{2}$ that are released during the cement production $[2,3]$. Technology development and its productivity are necessary, in order to maintain the sustainability and to reduce the production of $\mathrm{CO}_{2}$ emission in order to maintain eco-friendly environment. Hence, in recent years, biotechnology is practiced an increased level of interest. This requires a multidisciplinary perspective that holds the science of biology, chemistry and physics together and applies this knowledge to multifunctional geotechnical and environmental engineering applications. The idea of bio geotechnical engineering started spreading through the field of geotechnical engineering, in 2005, and bio geotechnical engineering is identified as an important research topic by the National Research Council [4]. Mitchell and Santamarina have presented the first detailed discussion of bio geotechnical engineering. The major topic of interest in these bio geotechnical studies is the improvement of soil via carbonate precipitation induced by urea hydrolysis, with most studies focusing on microbially induced calcite precipitation (MICP) [5]. The evidence of microorganism involvement in carbonate precipitation has led to the development of bio technology in the field of construction material $[6,7]$. In addition to that, the reduction of water hardness [8], heavy metal removal from soil and water $[9,10]$ has been investigated using the formation mechanism of bio cement with aid of different sources of urease. The reagents for bio cement are produced at relatively low temperatures compared to ordinary cement that involves heating ingredient to temperatures up to about $1500^{\circ} \mathrm{C}$. Therefore, bio cement has a potential to be used as an eco-friendly cement material with advantages of less energy to produce the cement and less release of greenhouse gases [8]. This cementation process can be conducted in-situ without disrupting the structure of original soil and has a potential to be used in both unsaturated and saturated applications [11]. There are three main groups of microorganisms that can induce the carbonate precipitation. They are photosynthetic microorganisms such as cyanobacteria and microalgae, sulphate reducing bacteria, and some species of microorganisms involved in nitrogen cycle (Bacillus pasteurii, Bacillus cereus, etc.) such as nitrogen fixing bacteria, nitrifying bacteria, denitrifying bacteria and saprobiotic bacteria through the processes of ammonification of amino acids, dissimilatory reduction of $\mathrm{NO}_{3}{ }^{-}$and degradation of urea or uric acid $[6,12]$. Currently, urease enzyme activity in most of bacteria metabolism process has been used widely as a tool to precipitate calcium carbonate. In addition to the microorganisms, urease is a widely occurring hexameric protein found in many higher order plants and some invertebrates as well as wide

*Corresponding author: Dilrukshi RAN, Graduate School of Engineering, Hokkaido University, Kita 13, Nishi 8, Kita-ku, Sapporo, Hokkaido 060-8628, Japan, Tel: +81-11706-6318; E-mail: nadilrukshi@yahoo.com

Received November 08, 2015; Accepted December 14, 2015; Published December 24, 2015

Citation: Dilrukshi RAN, Kawasaki S (2016) Effective Use of Plant-Derived Urease in the Field of Geoenvironmental/Geotechnical Engineering. J Civil Environ Eng 6: 207. doi:10.4172/2165-784X.1000207

Copyright: (c) 2016 Dilrukshi RAN, et al. This is an open-access article distributed under the terms of the Creative Commons Attribution License, which permits unrestricted use, distribution, and reproduction in any medium, provided the original author and source are credited. 
variety of tissues in humans. Several families of common plants are very rich in urease, including some varieties of beans, melons and squash, and the pine family [13]. Seed urease has been purified to homogeneity from several leguminous plants [14], while leaf urease has also been subjected to investigations [15]. Extraction of urease enzyme from most urease containing plant species is simple and the enzyme is readily available from laboratory suppliers also. The enzyme is approximately $12 \mathrm{~nm}$ in dimension [16]. The small size of a solubilized urease enzyme gives distinct advantage over ureolytic microbes during the penetration into very small pore spaces as nearly all known bacteria are greater than $300 \mathrm{~nm}$ in diameter, with the majority in the range of 500-5000 nm. Therefore, plant-derived urease can be applicable to much finer soils. Furthermore, exogenously added urease (i.e. Urease added as a free enzyme) has a limited lifespan and its activity and function decreases with time $[17,18]$. This limited lifespan is potentially advantageous in some engineering applications as the enzyme can naturally degrade and eliminate long term impacts to the ecosystem. However, microbial based urease will leave the organisms behind. Therefore, injection of ureolytic bacteria in to the ground involves many problems such as the obtaining approvals and licenses from government and the continuous monitoring of microbial ecology for safety [19]. MICP treatment may be limited to deep soil due to limitations of bacterial growth and movement in sub soil. MICP may also be limited to the soils containing limited amounts of fines due to the reduction in pore spaces in fine soils. Based on the size of microorganism, the applicability of bio modification is limited to GW, GP, SW, SP, ML, and organic soils [5]. Bacteria are not expected to enter through pore throats smaller than approximately $0.4 \mu \mathrm{m}$. In general, the microbial abundance is found to increase with the increase in particle size [20]. The habitable pores and traversable pore throats are found in coarse sediments and some clayey sediment at shallow depth. In clayey soil, bacteria are capable of reorienting and moving clay particles under low confining stress (at shallow depths). However, inability to make these rearrangements under high confining stresses limits bacterial activity at larger depths. Furthermore, sediment-cell interaction may cause puncture or tensile failure of the cell membrane. Similarly, at larger depths, silt and sand particles may crush and cause a reduction in pore spaces, reducing the biological activity [20]. Moreover, the production of urease active bacteria and isolation of pure ureolytic bacteria is one of the main costs for applying to bio cementation technology [21] without enrichment of urease positive bacteria from local environment [22]. The urease enzyme that is extracted from plant species is little expensive when purchased from lab supply, but lab grade enzyme is very effective [23]. However, plant urease can be applied as a crude extract instead of commercially purified urease. Crude extracts of jack bean (Canavalia ensiformis) have the potential to be used as a replacement for commercially available purified urease [24]. These are the factors that give some conceptions to the geotechnologists or biotechnologists to think and investigate about bio mineralization of calcite from plant-derived urease as a promising alternative for microbial urease for making bio cement.

\section{Urease Activity}

Urease (EC 3.5.1.5) is a nickel dependent metalloenzyme which catalyzes the hydrolysis of urea. One mole of urea is hydrolyzed intracellularly to one mole of ammonia and one mole of carbamate (Equation 1), which is spontaneously hydrolyzed to one mole of ammonia and one mole of carbonic acid (Equation 2). Ammonia and carbamate subsequently equilibrate in water to form bicarbonate and 2 moles of ammonium and hydroxide ions as described in Equation 3 and 4 [7].

$$
\begin{aligned}
& \mathrm{CO}\left(\mathrm{NH}_{2}\right)_{2}+\mathrm{H}_{2} \mathrm{O} \rightarrow \mathrm{H}_{2} \mathrm{COOH}+\mathrm{NH}_{3} \\
& \mathrm{NH}_{2} \mathrm{COOH}+\mathrm{H}_{2} \mathrm{O} \rightarrow \mathrm{NH}_{3}+\mathrm{H}_{2} \mathrm{CO}_{3} \\
& 2 \mathrm{NH}_{3}+2 \mathrm{H}_{2} \mathrm{O} \rightarrow 2 \mathrm{NH}_{4}^{+}+2 \mathrm{OH}- \\
& 2 \mathrm{OH}-+\mathrm{H}_{2} \mathrm{CO}_{3} \rightarrow \mathrm{CO}_{3}^{2-}+2 \mathrm{H}_{2} \mathrm{O}
\end{aligned}
$$

Total reaction:$$
\mathrm{CO}\left(\mathrm{NH}_{2}\right)_{2}+2 \mathrm{H}_{2} \mathrm{O} \rightarrow 2 \mathrm{NH}_{4}^{+}+\mathrm{CO}_{3}^{2-}
$$$$
\mathrm{Ca}^{2+}+\mathrm{CO}_{3}^{-2} \rightarrow \mathrm{CaCO}_{3}
$$

The presence of calcium ion in the system will lead to the precipitation of calcium carbonate once a certain level of super saturation is reached. Hausinger has shown that urease accelerates the hydrolysis of urea by a factor of $10^{14} \mathrm{in}$ comparison with the spontaneous reaction [25]. This fifth reaction raises the $\mathrm{pH}$ of the solution. This raise in $\mathrm{pH}$ creates an optimum condition for carbonate precipitation. The $\mathrm{NH}_{4}^{+}$and $\mathrm{CO}_{3}^{2-}$ produced from this reaction actually represent the final products of series of reactions. The $\mathrm{NH}_{4}^{+}$ions actually start out as $\mathrm{NH}_{3}$. When the ammonia reacts with water, it creates $\mathrm{OH}-$ ions, which raise the $\mathrm{pH}$ of the system. This raise in $\mathrm{pH}$ causes the carbonate precipitation. Functionally, ureases belong to the superfamily of amidohydrolases and phosphotriestreases [26]. The members of the amidohydrolases superfamily catalyze a variety of hydrolysis reactions utilizing amides, urease, phosphotriestreases and substituted triazines. The primary common feature of the urease enzymes is the presence of metal centers in their active sites, whose task is to activate the substrate and water for the reaction. Among other dinuclear metallohydrolases in the superfamily, ureases are unique in that they possess $\mathrm{Ni}$ (II) ions in the active site. Plant and fungal ureases are homo-oligomeric proteins of $90-\mathrm{kDa}$ identical subunits. Bacterial ureases are multimers of two- or three-subunit complexes. The bacterial and plant ureases have high sequence similarity, suggesting that they have similar threedimensional structures and a conserved catalytic mechanism $[27,28]$.

\section{Plant-derived Urease}

Several families of common plants are very rich in urease, including some varieties of beans, melons and squash, and the pine family [13]. It includes jack beans (Canvalia ensiformis), soybean (Glycine max) leaf and seeds, pigweeds (Chenopodium album) and mulberry leaf (Morusalba), etc. [29] and they help to catalyze the reaction of urea hydrolysis to form ammonium and carbonate ions. Many researches are investigating new plant species such as leaves rather than the seeds having urease activity. Some plant species having urease activity gathered from the literature are summarized in Table 1 . The beststudied plant urease is that from jack bean [30] which is identified as the first nickel metalloenzyme [31] and the urease from jack bean is the first enzyme crystallized [32]. In 1926, Sumner shows that urease is a protein. Molecular weight of jack bean urease is $480,000 \mathrm{Da}$ (480 $\mathrm{kDa}$ ) [33]. There are forty seven - $\mathrm{SH}$ groups in the urease species of molecular weight $480,000 \mathrm{Da}(480 \mathrm{kDa})$ and it has been estimated that 4 to 8 of these groups are essential for the activity [34]. Maximum catalytic activity of jack bean urease occurs at $65^{\circ} \mathrm{C}$ [35] and it is inactive at temperatures above $70^{\circ} \mathrm{C}$ [36]. The optimum $\mathrm{pH}$ for jack bean urease usually lies between 6.0-7.0 [37,38]. The urease isolated from chickpea seeds (Cicer arietinum L.) yields maximum activity at $\mathrm{pH} 7.2$ [39]. This result is similar to those reported for urease from jack bean [40] and pigeon pea [13] but different from that isolated from mulberry leaves [15]. Maximum urease activity of chickpea seeds obtains at temperature of $55^{\circ} \mathrm{C}$ and beyond that the enzyme denatures 
Citation: Dilrukshi RAN, Kawasaki S (2016) Effective Use of Plant-Derived Urease in the Field of Geoenvironmental/Geotechnical Engineering. J Civil Environ Eng 6: 207. doi:10.4172/2165-784X.1000207

\begin{tabular}{|c|c|c|c|}
\hline Plant Species & Urease Activity & Unit & References \\
\hline Prosopis farcta & $\begin{array}{l}36.52 \text { (Specific } \\
\text { Activity) }\end{array}$ & \multirow{5}{*}{ Units/mg } & \multirow{5}{*}{ [118] } \\
\hline Alhagi graecorm & 14.8 (Specific Activity) & & \\
\hline Melilotus indica & 7.23 (Specific Activity) & & \\
\hline Albizia lebbeck & 3.75 (Specific Activity) & & \\
\hline Sesbania & 0.78 (Specific Activity) & & \\
\hline $\begin{array}{l}\text { Canavalia ensiformis (Jack } \\
\text { Bean) }\end{array}$ & $2700-3500$ & \multirow{4}{*}{$\begin{array}{c}\mu \mathrm{mol} \text { urea/ } \\
\mathrm{min} \cdot \mathrm{mg}\end{array}$} & \multirow{4}{*}{ [119] } \\
\hline Glycine max (soy bean) & $650-800$ & & \\
\hline Cajanus cajan (pigeon pea) & 3120 & & \\
\hline $\begin{array}{l}\text { Gossyplum hirsutum (cotton } \\
\text { seeds) }\end{array}$ & 14.5 & & \\
\hline Equisetum arvense L. & 16.2 & \multirow{31}{*}{$\begin{array}{l}\mu \mathrm{g} \mathrm{NH}-\mathrm{N} / \\
\text { hour. } \mathrm{g}\end{array}$} & \multirow{31}{*}{ [120] } \\
\hline $\begin{array}{l}\text { Sciadopitys verticillata Sieb. } \\
\text { et Zucc. }\end{array}$ & 4.9 & & \\
\hline Houttuynia cordata Thunb. & 9.2 & & \\
\hline Lithocarpus edulis Nakai & 15.1 & & \\
\hline Quercus crispula Blume & 35 & & \\
\hline Humulus scandens Merrill & 23.9 & & \\
\hline Boehmeria longispica Steud. & 28.6 & & \\
\hline Rumex Acetosa L. & 15 & & \\
\hline Rumex japonicus Houtt. & 42.2 & & \\
\hline Polygonum lapathifolium L. & 6.2 & & \\
\hline Polygonum nodosum Pers. & 0 & & \\
\hline Polygonum perfoliatum L. & 0 & & \\
\hline $\begin{array}{l}\text { Polygonum cuspidatum Sieb. } \\
\text { et Zucc. }\end{array}$ & 2.6 & & \\
\hline Polygonum filiforme Thunb. & 8.9 & & \\
\hline Polygonum conspicuum Nakai. & 0 & & \\
\hline Polygonum aviculare L. & 1.8 & & \\
\hline Polygonum Blumei Meisn & 0 & & \\
\hline Polygonum multiforum Thunb. & 10.5 & & \\
\hline Chenopodium album L. & 32.6 & & \\
\hline Amaranthus bitum L. & 18.1 & & \\
\hline Amaranthus japonica Nakai & 22.4 & & \\
\hline Celosia cristata L. & 12.6 & & \\
\hline Amaranthus viridis $\mathrm{L}$. & 34.8 & & \\
\hline Amaranthus patulus Bertoloni & 27.6 & & \\
\hline Mirabilis jalapa L. & 83.8 & & \\
\hline Phytolacca americana L. & 26.1 & & \\
\hline Portulaca oleracea L & 26.4 & & \\
\hline Portulaca pilosa L. & 35.4 & & \\
\hline Stellaria Meglecta Weihe & 27.6 & & \\
\hline Ranunculuc glaber Makino & 26.4 & & \\
\hline Clematis flirida Thunb. & 0 & & \\
\hline
\end{tabular}

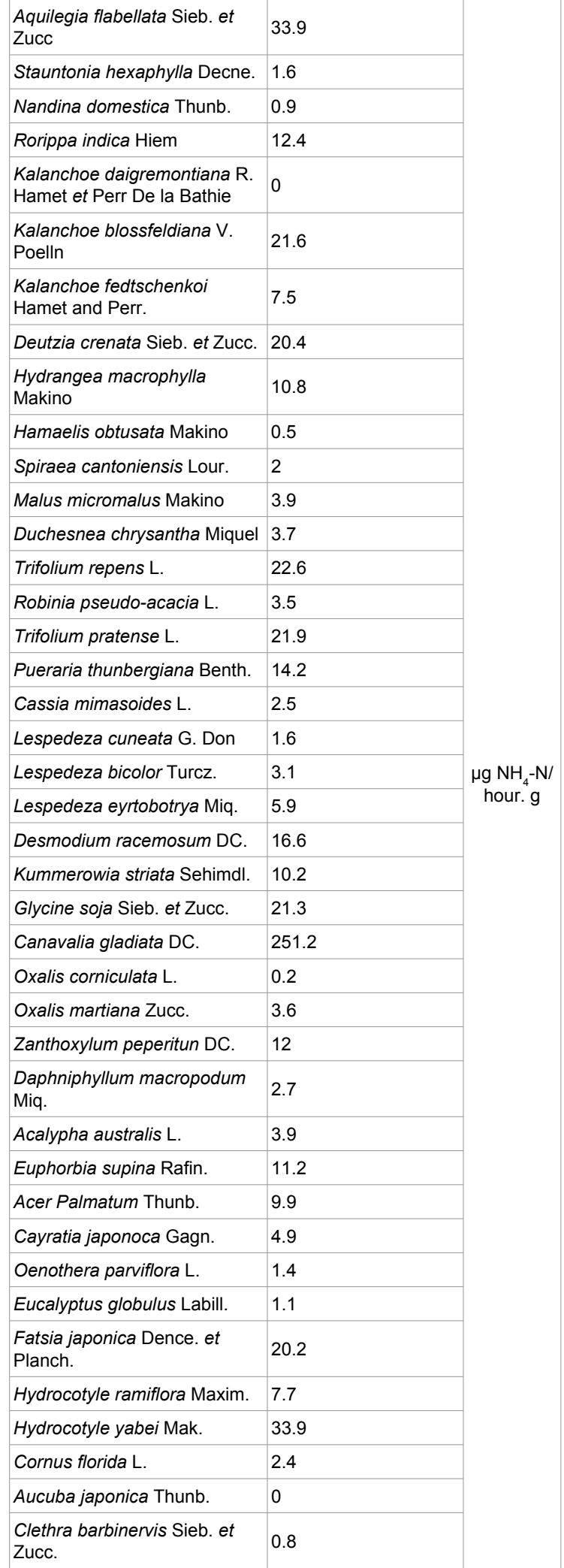




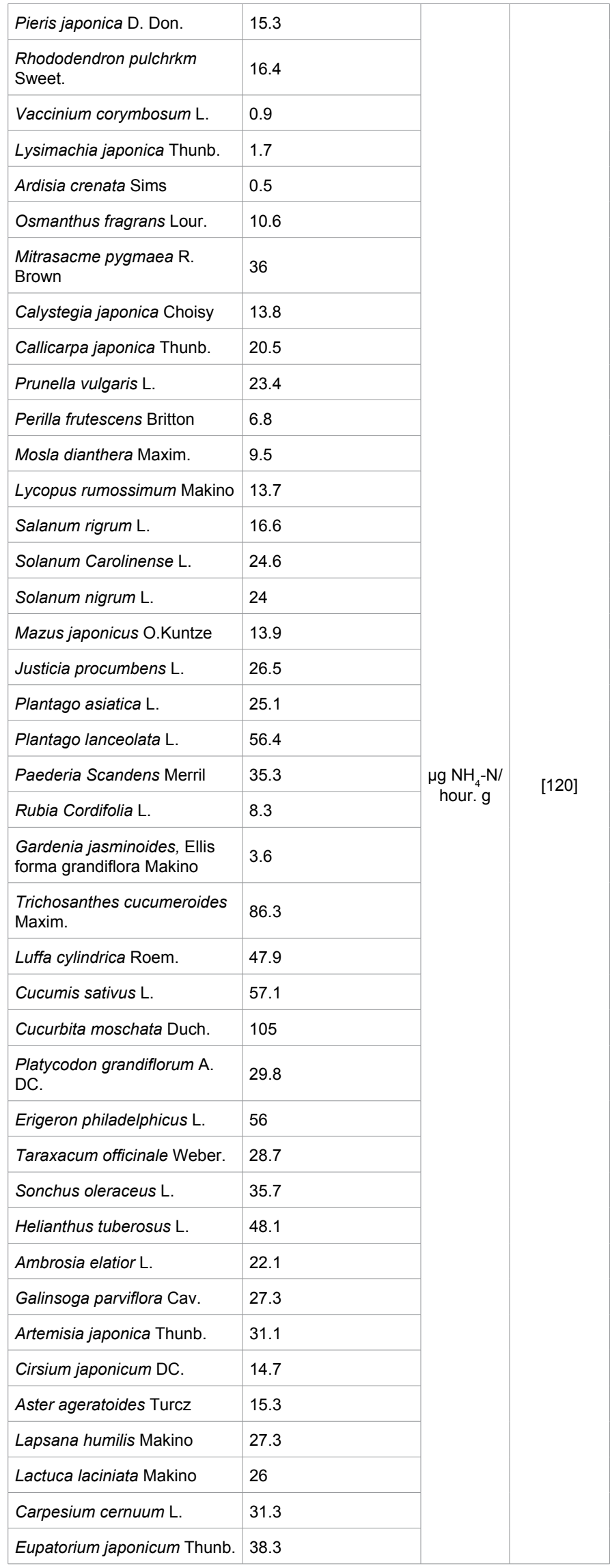

\begin{tabular}{|c|c|c|c|}
\hline Gnaphalium multiceps Wall. & 38.5 & \multirow{20}{*}{$\begin{array}{l}\mu \mathrm{g} \mathrm{NH}_{4}-\mathrm{N} / \\
\text { hour. } \mathrm{g}\end{array}$} & \multirow{20}{*}{ [120] } \\
\hline Bidens frondosa $\mathrm{L}$. & 42.9 & & \\
\hline $\begin{array}{l}\text { Siegesbeckia pubescens } \\
\text { Makino }\end{array}$ & 60.3 & & \\
\hline Xanthium Strmarium L. & 28.8 & & \\
\hline Solidago altissima $\mathrm{L}$. & 30.6 & & \\
\hline Artemisia vulgaris $\mathrm{L}$. & 52.8 & & \\
\hline Setaria viridis Beauv. & 54.8 & & \\
\hline Eleusine indica Gaertner & 45.1 & & \\
\hline Coix lachryma-jobi L. & 1.8 & & \\
\hline $\begin{array}{l}\text { Oplismenus undulatifolius } \\
\text { Roem. et Schult }\end{array}$ & 0 & & \\
\hline Pennisetum japonicum Trinius. & 62.1 & & \\
\hline $\begin{array}{l}\text { Eragrostis ferruginea, } \\
P \text {. Beauvois }\end{array}$ & 44.7 & & \\
\hline Miscanthus sinensis Anderss & 39.1 & & \\
\hline Cyperus microiria, Steud. & 3.6 & & \\
\hline Commelina communis L. & 36.9 & & \\
\hline Scilla Chinensis Benth. & 15.3 & & \\
\hline Hosta undulata Bailey & 24.2 & & \\
\hline Convallaria majalis L. & 32.8 & & \\
\hline Iris nertschinskia Lodd. & 53.1 & & \\
\hline Clivia miniata Regel & 0 & & \\
\hline
\end{tabular}

rapidly and thus loose its activity. This result is closely related to those reported by Das et al. [13] and Srivastava et al. [41] but differs from that stated by El-Shora [42]. Urease activity increases with substrate concentration. After reaching an optimum value, the urease activity decreases with rising urea concentration [39]. The rate of hydrolysis of urea is increased with an increase in urea concentrations until a maximum is reached, beyond which hydrolysis is decreased. The results can be explained by substrate inhibition at higher urea concentrations $[43,44]$. Pervin et al. has also studied the effect of various metal ions and chemicals on the activity of chickpea urease. The urease activity has increased in the presence of calcium ion at low concentrations like $3 \mathrm{mM}$ or less and decreased at higher calcium ion concentrations. Divalent cations like $\mathrm{Ba}^{2+}$ and $\mathrm{Mg}^{2+}$ slightly stimulate the enzyme at a concentration of 1-3 mM and $\mathrm{Na}^{+}$and $\mathrm{K}^{+}$produce little or no effect on the activity [42]. Heavy metals, such as $\mathrm{Cu}^{2+}, \mathrm{Zn}^{2+}, \mathrm{Pb}^{2+}$ and $\mathrm{Hg}^{2+}$ almost completely inhibit the enzyme activity. This has also been proved for pigeon pea urease [45] and jack bean urease $[46,47]$. The urease enzyme activity is completely inactivated when the concentration of $\mathrm{Hg}^{2+}$ is high enough [48]. Muskmelon (Cucumis melo) is another plant source of urease enzyme [49]. Kharbooza and Banggi are common names for muskmelon. Recently, urease from mulberry leaves (Morus alba) has also purified and characterized [15].

\section{Other Types of Ureases}

\section{Microbial urease}

Microbial (bacteria, fungi and algae) urease is an enzyme produced by ureolytic microorganisms and hydrolysis of urea is catalyzed in to ammonium and carbonate by this enzyme. The metabolic activities of these microbial sources promote the precipitation of calcium carbonate in the form of calcite crystals using produced carbonate, and calcium ions in the system. These crystals form bonds between 
sand grains and increase the strength and stiffness of the sand [50,51]. Microorganisms with ureolytic activity are found in soil and water as well as in human and animal bodies [52]. There are several bacterial sources for this enzyme such as Bacillus sphaericus, Sporosarcina pasteurii, Sporosarcina psychrophila, Proteus vulgaris, Myxococcus xanthus, Sporosarcina ureae, Pararhodobacter sp., Beijerinckia indica, Phanerochaete chrysosporium, Bacillus subtilis, etc. Wijngaarden et al. explain that the majority of studies on MICP have been used the micro-organism named Sporosarcina pasteurii (previously Bacillus pasteurii) having urease enzyme for stabilizing soils [53]. Potential geotechnical and geoenvironmental applications of MICP are reducing the liquefaction potential of soil, increasing the bearing capacity of foundations, fixing leakages of groundwater in underground constructions, controlling seepage or erosion of riverbanks or coastal dikes, constructing reservoirs and ponds in sandy soil, preventing piping of earth dam, enhancing the stability of soil slope, controlling settlement or soil deformation, decreasing soil expansion potential, sealing the drippings in the tunnels, fixing cracks on rocks, immobilizing sand surface in deserts, fixing soil surface to prevent aerosolization of soil surface pollutants, removal of heavy metals from contaminated environment, etc.

\section{Soil urease}

Soil ureases are partly extracellular being liberated during microbial and plant root metabolism and death. They are also intracellular as part of the soil biomass [54]. Soil urease activity is related to the vegetation of the soil [55]. Higher urease activity in soils under vegetation compared to vegetation free soils has been observed by Reddy et al. [56] and they attributed it to the higher microbial proliferation and microbial activity at the rhizosphere. The major factor that influence for the level and distribution of urease activity through the soil profile is the content of soil organic carbon [57,58]. However, this relationship is obviously modified within particular horizons by other soil properties such as reaction, gleying and soil texture [57]. According to the Myers and McGarity, urease activity in calcareous soils is lower than in non-calcareous soil. They have reported that in saline soils, urease activity is low [57]. Skujins has reported that in alkaline soils, the activity is much less, and it is also much less in carbonate rich soils, apparently because of detrimental effect of $\mathrm{Ca}^{2+}$ on the urease producing organisms [59]. Numerous studies show that the urease activity in soils increases with the increase in temperature from $10^{\circ} \mathrm{C}$ to $40^{\circ} \mathrm{C}$. In some soils, urease activity increases very markedly with the increase in temperature from $40^{\circ} \mathrm{C}$ to $70^{\circ} \mathrm{C}[37,60,61]$ but decreases rapidly above this temperature range $[61,62]$. The optimum
$\mathrm{pH}$ of soil urease activity reported in past is 6.5 to 7.0 [63] and it is similar to that of jack bean urease $[37,64,65]$.

Equilibrium between ammonium ion and ammonia gas occurs in aqueous solutions of ammonium salts [66]. When, enzyme activity is high in soil, the rate of hydrolysis of urea is increased and high soil $\mathrm{pH}$ and greater losses of gaseous ammonia can be observed. Although high ammonium ion concentration in soil is non- toxic, ammonia gas is extremely toxic to the plant [67]. Therefore, the loss of volatile ammonia and ammonia toxicity to germinate seedlings are major problems in urea fertilization.

\section{Methods for Evaluating Urease Activity}

There are several methods to determine urease activity such as manometric, titrimetric, colorimetric, potentiometric method as well as spectrophotometric method. Some of those methods are summarized in Table 2 . In these methods, urease can be examined by measuring substrate/products of the ureolytic reaction or byproducts of this reaction, such as ammonia, an increase in $\mathrm{pH}$ or conductivity as well as generated heat. A number of excellent assays are available for quantifying urease activity and analyzing its kinetic behavior [28]. More popularly, ammonia release during the ureolytic reaction can be detected with phenol-hypochlorite [68], Nessler's reagent [32], diacetyl monoxime method or Ehrlich's reagent method to allow colorimetric determination of activity and can be detected by ion-selective electrodes. It is possible to include $\mathrm{pH}$ indicators/ $\mathrm{pH}$ sensitive dyes in the assays or simply observe changes with $\mathrm{pH}$ electrodes since release of ammonia results in an increase in $\mathrm{pH}$. The amount of ammonia can also be monitored spectrophotometrically using a couple system with NADH-dependent glutamate dehydrogenase (ammonia is a substrate for this enzyme). The other product of the reaction, carbon dioxide, can be trapped and monitored by radiological methods with ${ }^{14} \mathrm{C}$-labeled urea as a substrate [69]. All of the methods described above are distinct in their sensitivities, ease of use, and susceptibility to interference. Two commonly employed assays mentioned above paragraph namely phenol-hypochlorite and Nessler's method are time consuming, incompatible with common buffers, require high temperature, non-homogenous true color solution and have the disadvantage of using harmful chemicals. Croston et al. explain some advantages, disadvantages and the cares that should be followed at titrimetric, $\mathrm{pH}$ change and conductimetric methods. The end point of the titrimetric method is not sharp and good results require extreme care in titration. The titration method requires appreciably more time than the others but gives direct measure of urease activity. The $\mathrm{pH}$ change method is simple in operation, however, the recorded

\begin{tabular}{|c|c|c|c|c|}
\hline Test Method & Test Item & Measurement & Remarks & References \\
\hline \multirow{3}{*}{ Titrimetric Method } & Soybean oil meal & $\begin{array}{c}\text { Volume of } \mathrm{NaOH} \text { required to finish the } \\
\text { titration }\end{array}$ & $\begin{array}{l}\text { * Application: In mixed-feed industry to identify the low } \\
\text { concentration of urease in soybean oil meal (when urea } \\
\text { and soybean oil meal are combined in cattle feeds) }\end{array}$ & {$[70]$} \\
\hline & Soybean meals & $\begin{array}{c}\text { Volume of } \mathrm{NaOH} \text { required to finish the } \\
\text { titration }\end{array}$ & $\begin{array}{l}\text { * Application: To determine urease in soybean meals of } \\
\text { high activity } \\
{ }^{*} \text { Recommended for all highly active meals }\end{array}$ & [121] \\
\hline & Jack Bean & $\begin{array}{l}\text { Color change of the p-Nitrophenol } \\
\text { indicator from yellow to colorless } \\
\text { during the titration }\end{array}$ & $\begin{array}{l}\text { *Limitation: This is not for determining the activity of } \\
\text { urease, from Bacillus pasteurii, U7127 } \\
\text { *Urease activity is reported as Units/g solid. }\end{array}$ & [122] \\
\hline $\begin{array}{l}\text { Spectrophotometric Stop } \\
\text { Rate Determination }\end{array}$ & - & $\begin{array}{l}\text { Absorbance is taken at } 480 \\
\mathrm{~nm} \text { wavelength using a } \\
\text { spectrophotometer }\end{array}$ & $\begin{array}{l}\text { *Urease activity is reported as Units/g enzyme (one unit } \\
\text { will liberate } 1.0 \mu \text { mole of } \mathrm{NH}_{3} \text { from urea per minute at } \mathrm{pH} \\
8.2 \text { at } 30^{\circ} \mathrm{C} \text {.) } \\
{ }^{*} \text { Nessler's reagent is used to determine } \mathrm{NH}_{3} \text { generated } \\
\text { from hydrolysis of Urea }\end{array}$ & [123] \\
\hline
\end{tabular}




\begin{tabular}{|c|c|c|c|c|}
\hline \multirow{3}{*}{ Caskey-Knapp method } & \multirow{3}{*}{ Soybean meal } & \multirow{3}{*}{ color change due to variation in $\mathrm{pH}$} & $\begin{array}{l}{ }^{*} \mathrm{pH} \text { indicator. phenol red solution (If sufficient urease is } \\
\text { present color change to deep red) }\end{array}$ & \multirow{3}{*}{ [124] } \\
\hline & & & $\begin{array}{l}\text { *Application: Food processing Industry to detect } \\
\text { inadequately heated soybean oil meal }\end{array}$ & \\
\hline & & & *Limitation: Cannot indicate excessive heat treatment & \\
\hline \multirow{3}{*}{$\begin{array}{l}\text { Modified Caskey-Knapp } \\
\text { method /PH Change } \\
\text { method (potenciometric } \\
\text { method) }\end{array}$} & Soybean oil meal & $\begin{array}{l}\mathrm{pH} \text { value using } \mathrm{pH} \text { meter with glass } \\
\text { electrode }\end{array}$ & $\begin{array}{l}\text { *Application: In food processing Industry (detecting } \\
\text { inadequately heated soybean oil meal) }\end{array}$ & [125] \\
\hline & $\begin{array}{l}\text { Soybean meal and } \\
\text { byproducts }\end{array}$ & $\begin{array}{l}\mathrm{pH} \text { value using } \mathrm{pH} \text { meter with glass } \\
\text { electrode }\end{array}$ & $\begin{array}{l}\text { *Application: In Soybean Industry (Detecting present in } \\
\text { soybean products like soy-bean meals, soy flour, and } \\
\text { mill feeds) }\end{array}$ & [126] \\
\hline & $\begin{array}{l}\text { Soybean meal and } \\
\text { byproducts }\end{array}$ & $\begin{array}{l}\mathrm{pH} \text { value using } \mathrm{pH} \text { meter with glass } \\
\text { electrode }\end{array}$ & $\begin{array}{l}\text { *Application: soybean Industry (Detecting urease } \\
\text { present in Soybean meal and its by-products) }\end{array}$ & [127] \\
\hline Conductimetric Method & Soybean & $\begin{array}{l}\text { Resistance in ohms (specific } \\
\text { conductance is reciprocal ohms) }\end{array}$ & Application: To study urease isolated from soybeans & [70] \\
\hline \multirow{2}{*}{$\begin{array}{l}\text { Wiffin's conductimetric } \\
\text { Method }\end{array}$} & $\begin{array}{l}\text { Bacteria (proteus } \\
\quad \text { vulgaris and } \\
\text { Sporosarcina pasteurii) }\end{array}$ & Conductivity & Urease activity is reported as $\mathrm{mM}$ urea hydrolysed $\mathrm{min}^{-1}$. & [71] \\
\hline & $\begin{array}{l}\text { Bacteria (Sporosrcina } \\
\text { pasteurii) }\end{array}$ & Conductivity & - & {$[87]$} \\
\hline \multirow{12}{*}{ Colorimetric Method } & Soybean meal & $\begin{array}{l}\text { The absorbance (Optical density) is } \\
\text { measured at } 430 \mu \mathrm{m} \text { Wavelength } \\
\text { using the spectrometer }\end{array}$ & $\begin{array}{l}\text { *Application: To determine urease activity of soybean meal } \\
\text { *Urease activity was reported as mg/l urea decomposed. } \\
\text { (An unit of urease activity is defined as one milligram per } \\
\text { liter of urea decomposed) }\end{array}$ & [128] \\
\hline & Plant coedc & Color change due to variation in $\mathrm{nH}$ & $\begin{array}{l}{ }^{*} \mathrm{pH} \text { indicator red cabbage extract }(\mathrm{At} \mathrm{pH} 7 \text {, the solution } \\
\text { is violet/blue and in the acidic range it turns red and in } \\
\text { alkaline range it turns green) }\end{array}$ & 120 1301$]$ \\
\hline & rlani seeds & coror crange uue to vanation in рп & $\begin{array}{l}\text { * } 1 \% \text { or } 2 \% \text { phenolphfhalein solution and bromothymol blue } \\
\text { are alternatives for } \mathrm{pH} \text { indicator (it turns from yellow to blue } \\
\text { in } \mathrm{pH} 7.6 \text { ) }\end{array}$ & {$[129,100]$} \\
\hline & & & $\begin{array}{l}\text { *Nessler's reagent is used to determine } \mathrm{NH}_{3} \text { generated } \\
\text { from hydrolysis of Urea }\end{array}$ & \\
\hline & Soybean & $\begin{array}{l}\text { ADSordance is taken at } 405 \mathrm{~nm} \\
\text { wavelength using a spectrometer }\end{array}$ & $\begin{array}{l}{ }^{*} \text { One unit of urease activity is defined as the amount of } \\
\text { enzyme required to liberated } 1.0 \mu \mathrm{M} \text { of } \mathrm{NH}_{3} \text {, from urea } \\
\text { per min at } \mathrm{pH} 8.0 \text { and temperature } 30^{\circ} \mathrm{C} \text { ) }\end{array}$ & [131] \\
\hline & Jack Bean meal & $\begin{array}{l}\text { Absorbance (optical density) is } \\
\text { measured at } 630 \mathrm{~nm} \text { wavelength, using } \\
\text { the spectrometer (Phenol Hypochloride } \\
\text { solution was added to develop color) }\end{array}$ & - & [132] \\
\hline & Soil & $\begin{array}{l}\text { Absorbance (optical density) is } \\
\text { measured at } 690 \mathrm{~nm} \text { wavelength, } \\
\text { using the spectrophotometer }\end{array}$ & $\begin{array}{l}\text { *Urease activity is expressed as } \mu \mathrm{g} \mathrm{N} \text { hydrolyzed/g dry } \\
\text { soil per } 2 \text { hour at } 37^{\circ} \mathrm{C} \text {. }\end{array}$ & [133] \\
\hline & Soil & $\begin{array}{l}\text { Absorbance (optical density) is } \\
\text { measured at } 690 \mathrm{~nm} \text { wavelength, } \\
\text { using the spectrophotometer }\end{array}$ & $\begin{array}{l}\text { *Urease activity is calculated as mole of ammonium } \\
\text { released per hour per gram of soil. }\end{array}$ & [134] \\
\hline & Pararhodobacter sp. & Color change due to variation in $\mathrm{nH}$ & $\begin{array}{l}{ }^{*} \mathrm{pH} \text { indicator: Cresol red solution (yellow to purple has } \\
\text { been observed from } \mathrm{pH} 7.2 \text { to } \mathrm{pH} 8.8 \text { ) }\end{array}$ & {$[135]$} \\
\hline & & Color change due to varlation in pH & $\begin{array}{l}\text { *Medium used to isolate microorganism in ZoBell2216E } \\
\text { medium }\end{array}$ & [135] \\
\hline & Bacteria & - & ${ }^{*}$ Christensen's urea medium was used & [136] \\
\hline & Bacteria & $\begin{array}{l}\text { Absorbance (optical density) } \\
\text { is measured at } 430 \mathrm{~nm} \text { and } \\
560 \mathrm{~nm} \text { wavelengths, using the } \\
\text { spectrophotometer }\end{array}$ & $\begin{array}{l}\text { *Urease activity as Units/ml enzyme (one unit of urease } \\
\text { activity corresponds to the amount of enzyme that } \\
\text { hydrolyzes } 1 \mu \mathrm{M} \text { of urea per minute) }\end{array}$ & [137] \\
\hline
\end{tabular}

Table 2: Methods for evaluating urease activity.

differences between samples at room temperature may be very small and frequent checking of the meter is required to minimize errors. The sensitivity of the titrimetric and $\mathrm{pH}$-change methods can be improved by using $50^{\circ} \mathrm{C}$ or $60^{\circ} \mathrm{C}$ reaction temperatures. However, from laboratory experiences of Croston et al. and his team, their opinion is that maximum precision is obtained by the conductimetric method [70]. It is easy to identify urease activity. However, quantifying the urease activity is time consuming. Although there are some analytical techniques to determine urease activity, the use of spectro-photometric method is still well popular. Specific urease activity can also be obtained quantitatively from conductivity method proposed by Whiffin [71]. This method of measuring conductivity is simple when compare with other methods found in literature. Wiffin's above method is suitable for measuring urease activity quantitatively, because this method is simple and not using expensive and harmful chemicals. Initially, this method has been used to measure urease activity of microorganisms [71]. We have used this conductivity method for measuring urease activity of watermelon (Citrullus vulgaris) seeds extract [72].

\section{Immobilization of Urease Enzyme}

The use of enzymes is limited due to their limited availability, high cost, instability and the limited possibility of economic recovery of these soluble biocatalysts from a reaction mixture. These problems can be solved by immobilizing of enzymes [73]. Enzyme immobilization can be defined as confining the enzyme molecules to a distinct phase 
from the one in which the substrates and the products are present. This may be achieved by fixing the enzyme molecules to or within some suitable material. It is critical that the substrates and the products move freely in and out of the phase to which the enzyme molecules are confined. Immobilization of enzymes can be done by various methods such as entrapment, physical adsorption, membrane confinement and covalent binding. Enzyme molecules do not necessarily render them immobile in some methods of immobilization. They move freely within their phase in entrapment and membrane confinement, and they are in fact, immobile in adsorption and covalent binding [74]. The materials used for immobilization of enzymes are called carrier matrices and they are usually inert polymers or inorganic materials. The ideal carrier matrix has low cost, inertness, physical strength, stability, and regenerability after the useful lifetime of the immobilized enzyme, enhancement of enzyme specificity, reduction in product inhibition, a shift in the $\mathrm{pH}$ optimum for enzyme action to the desired value for the process, and reduction in microbial contamination and non-specific adsorption. However, most matrices possess only some of the above features. Therefore, carrier matrix for the immobilization of an enzyme must be chosen with care keeping in view the properties and limitations of various matrices. In the process of adsorption, the enzyme molecules adhere to the surface of carrier matrix due to a combination of hydrophobic effects and the formation of several salt links per enzyme molecule. The binding of enzyme molecules to the carrier matrix is usually very strong, but it may be weakened during use by many factors such as addition of substrate, $\mathrm{pH}$ or ionic strength. In covalent binding, the enzyme molecules are attached to the carrier matrix by covalent bonds. As a result the strength formation occurs with the side chains of amino acids of the enzyme, their degree of reactivity being dependent on their charged status. Roughly, the following relation is observed in reactivity. $-\mathrm{S}>-\mathrm{SH}>-0>-\mathrm{NH}_{2}>-$ $\mathrm{COO}>\mathrm{OH}>>-\mathrm{NH}_{3}^{+}$. In the case of entrapment, enzyme molecules are held or entrapped within suitable gels or fibers and there may or may not be covalent bond formation between the enzyme molecules and the matrix. A non-covalent entrapment may be viewed as putting the enzyme molecule in a molecular cage just as a caged bird/animal. When covalent binding is also to be generated, the enzyme molecules are usually treated with a suitable reagent. In membrane confinement, enzyme molecules in an aqueous solution may be confined within a semipermeable membrane which, ideally, allows a free movement in either direction to the substrates and products but does not permit the enzyme molecules to escape [74]. Among the techniques used for immobilization, entrapment is favored due to various reasons. Non toxicity of the matrix, variation in the bead size of gel and high percentage of immobilization are some reasons. Considering these things, calcium alginate mediated entrapment has attracted much attention [75]. Immobilization changes original enzyme properties like storage stability, kinetic parameter and customizes them for specific applications [76,77]. Furthermore, immobilization of enzymes enhances their thermal stabilities [54]. For example, glucose isomerase denatures at $45^{\circ} \mathrm{C}$ in solution, however, it is stable for about 1 year even at $65^{\circ} \mathrm{C}$ when suitably immobilized. Recovery of enzyme may also reduce effluent handling problems [74]. Enzymes can be used repeatedly only if they can be recovered from the reaction mixtures. Immobilization permits their repeated use since such enzyme preparations can be easily separated from the reaction system. Immobilized enzymes can be used in non-aqueous systems as well. Continuous production systems can be used, which is not possible with free enzymes and enzymes can be used at much higher concentrations than free enzymes.

\section{Use of Plant-derived Urease in Geoenvironmental/ Geotechnical Engineering}

Nowadays, the urease enzyme is widely used in different fields of industries such as medicinal, construction, agricultural, food, etc. Different kinds of ureolitic bacteria and micro algae, soil urease and plant urease have applied for the above fields. Currently, the potential for using plant-derived urease enzyme to precipitate carbonate (mainly calcite) through urea hydrolysis in several environmental and geotechnical engineering applications has been demonstrated. The aim of this section is to summarize the existing and potential applications in $\mathrm{CaCO}_{3}$ precipitation using plant- derived urease.

\section{$\mathrm{CaCO}_{3}$ precipitation}

$\mathrm{CaCO}_{3}$ (calcite) precipitation may be achieved by many different processes and enzymatic hydrolysis of urea is the most energy efficient process [78] and it has been proposed as an engineering technique in the early 1990 [79-81]. Calcite precipitation is a relatively straightforward chemical process controlled mainly by four key elements. These are the concentration of calcium ions, concentration of dissolved inorganic carbon (DIC), $\mathrm{pH}$ and availability of nucleation sites [71,82,83]. In addition, several environmental parameters such as salinity, temperature may also affect for the performance of calcite precipitation [81,84-86]. The rate of calcite precipitation is also depending on the injecting rate of chemicals to the soil and the rate of $\mathrm{pH}$ rise to prompt precipitation [87]. The rate of precipitation helps to achieve uniform cementation in situ. Higher rates of calcite precipitation lead to plugging at the injection source and slower rates of precipitation allow uniform delivery of the chemicals. Cementation between soil particles can be improved by adding impurities which can change crystal form as found in nature [88]. As an example, the presence of $\mathrm{Mg}$ can create $\mathrm{Mg}$-calcite having different crystals from those of calcite [89]. Larger amount of $\mathrm{Mg}$ contribute to form dolomite $\left(\mathrm{CaMg}\left(\mathrm{CO}_{3}\right)_{2}\right)$ or magenesite $\left(\mathrm{MgCO}_{3}\right)$. Both of them can resist against acid more than calcite [90]. The resistance against acetic acid is stronger for the cementation with $\mathrm{Mg} / \mathrm{Ca}$ ratio of 0.5 than calcite without magnesium, and UCS value estimate as $3.2 \mathrm{MPa}$ for $\mathrm{Mg} / \mathrm{Ca}$ ratio of 0.5 and $1 \mathrm{MPa}$ for calcite without magnesium [91]. Ismail et al. explain that the shape and the angularity of the soil particles have a great influence on the strength increase. The rounder and smoother particles have larger contact point result in a lower consumption of calcite crystals in order to achieve the same strength as for sharp and pointy particles [92]. Soil particle size is also a factor that effects for the precipitation of calcium carbonate [87]. Well graded and coarser sands have a higher rate of precipitation than finer and poorly graded sands. Very coarse and very fine soils like gravel and silts respectively also take a much longer time to increase shear wave velocity due to the limited rate of permeability in fine soils and the limited number of particle contacts in the very coarse soils. Calcium carbonate forms three anhydrous polymorphs named as calcite, aragonite and vaterite, three other hydrated crystalline phases named as mono hydrocalcite $\left(\mathrm{CaCO}_{3} \cdot \mathrm{H}_{2} \mathrm{O}\right)$, ikaite $\left(\mathrm{CaCO}_{3} \cdot 6 \mathrm{H}_{2} \mathrm{O}\right)$, and amorphous calcium carbonate (ACC) with differences in short range order and degree of hydration [93-97]. Rodrigues-Navarro et al. explains that the efficiency of bio deposition treatment depends on the type and structure of the precipitated $\mathrm{CaCO}_{3}$ polymorphs (Vaterite or calcite). More pronounced consolidating effect can be seen in welldeveloped calcite crystals rather than tiny acicular vaterite crystal [98].

\section{Existing and potential applications of $\mathrm{CaCO}_{3}$ precipitation using plant-derived urease}

Attempts to use plant-derived urease enzyme to precipitate $\mathrm{CaCO}_{3}$ 
Page 8 of 13

have made during past years to diminish the hydraulic conductivity of soils, to reinforce the loose soils and to prevent soil erosion. However, all of these applications are limited to laboratory scale and any kind of field application has not reported so far. Calcite precipitation using jack bean urease has been investigated to improve the mechanical properties of sand [99]. As a result of that, unconfined compressive strength (UCS) of $317 \mathrm{kPa}$ has been achieved, compared to that of sand without jack bean urease. The highest strength of the specimen has been obtained using calcium chloride stock solution rather than the other stock solutions of calcium sources (calcium hydroxide and calcium nitrate). Nemati and Voordouw have investigated plant urease induced calcite formation, plugging studies in an unconsolidated porous media system and plugging studies of Berea sandstone in a core-flooding system [100]. Jack bean urease having urease activity of 26,100 Units/g solid has been used for the study. According to the results of the study on plugging of unconsolidated porous media by enzymatically formed $\mathrm{CaCO}_{3}$, a significant decrease in permeability of porous media has been observed. At low concentration of enzyme $(0.03 \mathrm{~g} / \mathrm{l})$, the extent of plugging enhance with the increase in temperature from $22^{\circ} \mathrm{C}$ to $30^{\circ} \mathrm{C}$. Although the temperature is a factor that influence for carbonate precipitation, its influence is less with high concentrations of enzyme used in this study. However, Nemati and Voordouw, explain that proportional increase of reactants and enzyme concentrations above a certain level inhibit the urease activity and decrease the quantity of produced $\mathrm{CaCO}_{3}$ and plugging of porous media. Another attempt to find a method to create building materials using precipitated $\mathrm{CaCO}_{3}$ has been done by Bull with the aid of jack bean (Canavalia ensiformis) urease from Sigma-Aldrich Co. LLC. Specific activity of the jack bean urease used in the study is 15,000-50,000 Units/g solid. They have obtained uniform cemented specimens by dissolving urea and $\mathrm{CaCl}_{2}$ in one solution and urease in another solution. After curing, and air drying for 2 weeks, maximum UCS of $319 \mathrm{kPa}$ and an elastic modulus of approximately $10 \mathrm{MPa}$ have been obtained. Bull has also observed that $\mathrm{CaCO}_{3}$ cementation is not successful when solutions with high concentrations of $\mathrm{CaCl}_{2}$ and urea [101]. Hence, it is beneficial to study tolerable limits of concentrations of each solution for a better output. Neupane et al. have considered plant urease (jack bean) induced $\mathrm{CaCO}_{3}$

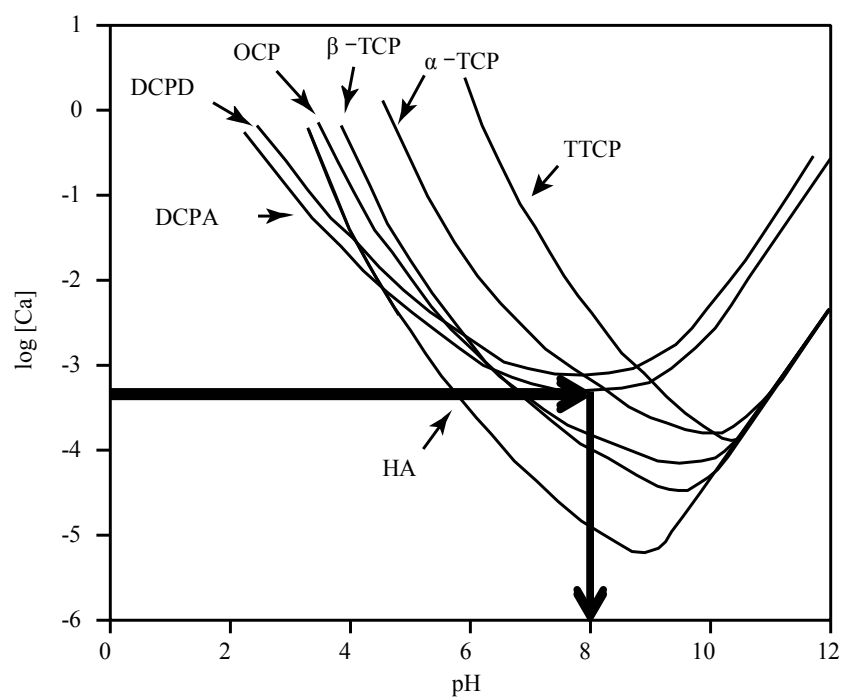

Figure 1: Solubility phase diagrams for the ternary system, $\mathrm{Ca}(\mathrm{OH})_{2}$ $\mathrm{H}_{3} \mathrm{PO}_{4}-\mathrm{H}_{2} \mathrm{O}$, at $25^{\circ} \mathrm{C}$, showing the solubility isotherms of $\mathrm{CaHPO}_{4}(\mathrm{DCPA})$, $\mathrm{CaHPO}_{4} \cdot 2 \mathrm{H}_{2} \mathrm{O}$ (DCPD), $\mathrm{Ca}_{8} \mathrm{H}_{2}\left(\mathrm{PO}_{4}\right)_{6} .5 \mathrm{H}_{2} \mathrm{O}(\mathrm{OCP}), \alpha-\mathrm{Ca}_{3}\left(\mathrm{PO}_{4}\right)_{2}(\alpha-\mathrm{TCP}), \beta-$ $\mathrm{Ca}_{3}\left(\mathrm{PO}_{4}\right)_{2}(\beta-\mathrm{TCP}), \mathrm{Ca}_{4}\left(\mathrm{PO}_{4}\right)_{2} \mathrm{O}(\mathrm{TTCP})$, and $\mathrm{Ca}_{10}\left(\mathrm{PO}_{4}\right)_{6} \cdot(\mathrm{OH})_{2}(\mathrm{HA})[107]$.

\begin{tabular}{|c|c|c|}
\hline $\mathrm{Ca} / \mathrm{P}$ ratio & Compound & Abbreviation \\
\hline 0.5 & $\begin{array}{l}\text { Monocalcium phosphate monohydrate } \\
\qquad\left(\mathrm{Ca}\left(\mathrm{H}_{2} \mathrm{PO}_{4}\right)_{2} \cdot \mathrm{H}_{2} \mathrm{O}\right)\end{array}$ & MCPM \\
\hline 0.5 & $\begin{array}{l}\text { Monocalcium phosphate anhydrate } \\
\left(\mathrm{Ca}\left(\mathrm{H}_{2} \mathrm{PO}_{4}\right)_{2}\right)\end{array}$ & MCPA \\
\hline 1 & $\begin{array}{l}\text { Dicalcium phosphate dihydrate } \\
\left(\mathrm{CaHPO}_{4} \cdot 2 \mathrm{H}_{2} \mathrm{O}\right)\end{array}$ & DCPD \\
\hline 1 & $\begin{array}{l}\text { Dicalcium phosphate anhydrate } \\
\left(\mathrm{CaHPO}_{4}\right)\end{array}$ & DCPA \\
\hline 1.33 & $\begin{array}{l}\text { Octacalcium phosphate } \\
\left(\mathrm{Ca}_{8}\left(\mathrm{HPO}_{4}\right)_{2}\left(\mathrm{PO}_{4}\right)_{4} \cdot 5 \mathrm{H}_{2} \mathrm{O}\right)\end{array}$ & OCP \\
\hline 1.5 & $\begin{array}{l}\text { A-tricalcium phosphate } \\
\quad\left(\mathrm{\alpha}-\mathrm{Ca}_{3}\left(\mathrm{PO}_{4}\right)_{2}\right)\end{array}$ & $\alpha-T C P$ \\
\hline 1.5 & $\begin{array}{l}\text { B-tricalcium phosphate } \\
\quad \beta-\mathrm{Ca}_{3}\left(\mathrm{PO}_{4}\right)_{2}\end{array}$ & $\beta-\mathrm{TCP}$ \\
\hline $1.2-2.2$ & $\begin{array}{l}\text { Amorphous calcium phosphate } \\
\qquad\left(\mathrm{Ca}_{x}\left(\mathrm{PO}_{4}\right)_{y} \cdot \mathrm{nH} \mathrm{H}_{2} \mathrm{O}\right)\end{array}$ & $\mathrm{ACP}$ \\
\hline $1.5-1.67$ & $\begin{array}{c}\text { Calcium-deficient hydroxyapatite } \\
\left(\mathrm{Ca}_{10-x}\left(\mathrm{HPO}_{4}\right)_{x}\left(\mathrm{PO}_{4}\right)_{6-x}(\mathrm{OH})_{2-x}\right)(0<x<1)\end{array}$ & $\mathrm{CDHA}$ \\
\hline 1.67 & $\begin{array}{l}\text { Hydroxyapatite } \\
\left(\mathrm{Ca}_{10}\left(\mathrm{PO}_{4}\right)_{6}(\mathrm{OH})_{2}\right)\end{array}$ & HA \\
\hline 2 & $\begin{array}{l}\text { Tetracalcium phosphate } \\
\qquad\left(\mathrm{Ca}_{4}\left(\mathrm{PO}_{4}\right)_{2} \mathrm{O}\right)\end{array}$ & TTCP \\
\hline
\end{tabular}

Table 3: Biologically relevant calcium orthophosphates [110].

precipitation technique for both small scale laboratory samples and samples in drum cans with a diameter of $56 \mathrm{~cm}$ and a height of $85 \mathrm{~cm}$ to evaluate the applicability of this technique for larger-scale applications. They have reported that the amount of precipitated calcite helps to modify the mechanical properties of sandy soil. However, mechanical tests using the same grouting condition have not conducted [102]. Hamdan et al. have conducted laboratory column tests (Acrylic tube tests and Triaxial tests) for cemented specimens made using silica sand, urea, calcium chloride and plant-derived urease, and obtained significant strength increase over non-cemented specimens at the same relative density. X-Ray Diffraction (XRD) analysis and Scanning Electron Microscopy (SEM) observations confirm that calcium carbonate (specifically calcite) is the cementing agent, and acid digestion perform to determine the amount of $\mathrm{CaCO}_{3}$ [103]. In addition to the urease from jack bean, some investigations have been done by using other types of seeds urease. Sword beans (Canavalia gladiate) urease is an example. The permeability as well as strength characteristics have been examined using sword beans urease [104]. The permeability of the improved samples has been reduced by more than one order of magnitude. Maximum unconfined compressive strength value obtained is $1620 \mathrm{kPa}$. An increase in compressive strength up to 1.6 $\mathrm{MPa}$ has also been obtained for oven dried specimens made using commercially available urease, with the activity of 2970 Units/g [105]. The strength enhancement and permeability reduction of subsurface soils are essential features for geotechnical engineering applications. It is necessary to achieve UCS value of $100 \mathrm{kPa}$ to avoid ground liquefaction during earthquakes [106]. This target value is successfully achieved by the past research studies based on plant-derived urease induced calcite precipitation. Hence, this technique can be applied for ground reinforcement. However, it is necessary to investigate the initial ground condition for soil type, soil $\mathrm{pH}$, contaminants in the soil, permeability characteristics, etc. before applying this technique in-situ in large scale. The homogenous, well-controlled distribution of $\mathrm{CaCO}_{3}$ should also be achieved prior to the real field applications. Therefore, future investigations should focus on these areas to get maximum output from this technique. We studied about plant-derived urease (seeds of watermelon) induced Calcium Phosphate Compound (CPC) 


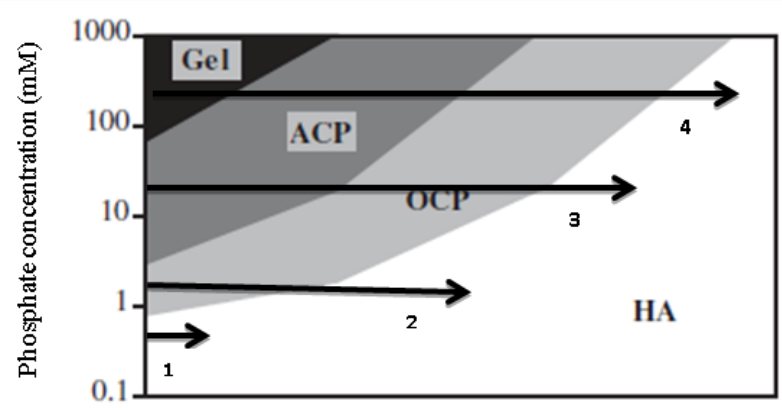

Time

Figure 2: Formation, stability, and hydrolysis of calcium phosphates as a function of phosphate concentration $(\log (P))$ in solutions of amorphous calcium phosphate (ACP) at neutral $\mathrm{pH}$. OCP: Octacalcium Phosphate; HA: Hydroxyapatite [107]

precipitation instead of $\mathrm{CaCO}_{3}$ precipitation [72]. CPC precipitation mechanism is highly dependent on its $\mathrm{pH}$ (Figure 1) [107] which can be increased by catalyzing the hydrolysis of urea using plant-derived urease. There are 11 CPCs with various calcium-to-phosphate $(\mathrm{Ca} / \mathrm{P})$ molar ratios in the ternary system of $\mathrm{Ca}(\mathrm{OH})_{2}-\mathrm{H}_{3} \mathrm{PO}_{4}-\mathrm{H}_{2} \mathrm{O}$ (Table 3 ). All CPCs are easy to dissolve in acidic solution and tend to precipitate in $\mathrm{pH}$ around 8-10. As an example, highest precipitation (least $\mathrm{Ca}^{2+}$ ion concentration) of DCPA can be obtained at $\mathrm{pH}$ around 8 as indicated by arrows in Figure 1. It is required alkaline $\mathrm{pH}$ more than around 8 for precipitating CPCs other than DCPA and DCPD. Gel-like or amorphous CPCs change into HA over time (Figure 2) [107,108]. The change rate is dependent on both $\mathrm{pH}$ and the concentrations of calcium and phosphate ions. HA forms directly in solutions with low super saturation levels (indicated by arrow 1 in Figure 2), as the concentration of phosphate ions increase, less stable phases of calcium phosphate compounds (e.g. ACP and OCP) form initially and transform into HA over time (indicated by arrows $2-4$ in Figure 2). Therefore, CPCs hardens after injection into soil and rock because of the self-setting mechanism [109] and hardening rate can be controlled by $\mathrm{pH}$ as well as phosphate ion concentrations. Out of all CPCs, the highest strength can be obtained from HA. CPCs exist as phosphate rocks (mainly fluoroapatite) in the natural environment and as an important inorganic substance (mainly hydroxyapatite, HA) in living organisms [110]. Phosphate and calcium stock solutions can be made from fertilizers, and calcium and phosphate can also be extracted from the bones of livestock and the shells of marine animals, [111]. CPCs that precipitate after grout injection are non-toxic. Unlike concrete, reexcavated muck that consists of soil, rock, and CPC grout is recyclable as an agricultural fertilizer. These advantages make it suitable for geotechnical applications [111]. In our study, UCS of more than 100 $\mathrm{kPa}$ was obtained by selecting superlative proportions of urea and urease enzyme with calcium acetate and dipotassium phosphate as calcium and phosphate stock solutions, respectively. In CPC precipitation method, it is very important to select superlative proportions of urea and urease enzyme for obtaining a $\mathrm{pH}$ for highest precipitation of CPC. This novel application may be important for the biocementation using plant-derived urease in future. The present study was carried out as a fundamental study on improving the strength of sand by using CPCs. We are planning to conduct further laboratory studies on CPCs for different types of soils having different permeability characteristics to use as a practical-scale experiment in actual ground in future. Most of the studies done in literature were focused on urea as ammonia source to complete the carbonate precipitation process. However, urea is a key raw material to produce fertilizer. Hence, the price of urea may become high with the demand for fertilizer. Under economical point of view, it is problematic to use urea at the carbonate precipitation process [112]. Therefore, it is economical to investigate carbonate precipitation using novel ammonia sources. Soil erosion due to wind and surface water runoff is a major environmental issue as it contaminates rivers, streams and ground water, and deposition of eroded soil in streams and rivers cause to unexpected flooding. Plantderived urease induced carbonate cementation has been proposed as a promising application for the stabilization of soil against wind and surface water erosion [23]. Knorr has obtained significant strength and relatively high resistance to water erosion due to carbonate cementation. This is a significant evidence to study this method deeply as an alternative method for controlling dust through carbonate precipitation. It is clear that the urease induced calcite precipitation can be expected at the presence of calcium ion in the system with suitable conditions such as $\mathrm{pH}$, temperature, etc. It has a potential to be used to reduce water hardness. The amount of water hardness depends upon the amount of dissolved ions of calcium and magnesium in the water. The presence of a high concentration of calcium ions $\left(500-1500 \mathrm{mgl}^{-1}\right)$ in the water causes severe problems [113]. The hard water can cause to precipitate minerals as carbonate, phosphate and/or gypsum in pipelines causing many problems [113] and reduce the effectiveness of use of soap for bathing and laundry. There are many commercial ways of treating hard water including water filters, water softeners, electromagnetic water conditioners and reverse osmosis [114]. These methods are complex and expensive to use in large scale. Plant-derived urease induced calcite precipitation may be a good solution. It is nontoxic and no need to remove bacteria as use during microbial urease. However, it is necessary to investigate the functionality of plant urease under different temperatures, and tolerable concentrations of calcium ions in the system. Hammes et al. (2003) have considered the potential of removing $\mathrm{Ca}^{2+}$ ions from industrial waste waters by MICP. The calcium ions removal up to $90 \%$ from the waste water can be achieved by adding low concentrations of urea $\left(0-16 \mathrm{gl}^{-1}\right)$ [115]. This kind of approach can also be considered using plant urease. Future investigations should be focused on novel sources of urease to deal with many environmental issues with sustainable and eco-friendly manner. Jroundi et al. explain that a lot of the world heritage listed buildings and statuaries are built out of carbonate stones especially marble and limestone. These are typically susceptible to physical erosion, chemical weathering and bio-deterioration which lead to a threat for the cultural and historical heritage. It has a possibility to apply the plant-derived urease induced carbonate precipitation technique to create a consolidated surface layer by spraying the biogrout solution straight onto the surface of the buildings or statuaries in order to prevent further erosion. This kind of preservation would take place through the strengthening of the existing bonds of the sediments in the existing stone [116]. With rapid urbanization, soil and water pollution are threatening not only to human health but also to the entire living organisms in environment. In order to maintain a good quality of soil and water and keep them free from contamination, continuous efforts have made to develop technologies to remove contaminants. Physicochemical methods are widely used for remedying polluted soil and water, especially at a small scale. However, high costs and side effects may cause to limit those methods for a large scale of remediation. Ureolytically-driven calcium carbonate precipitation is a basis for a promising in-situ remediation of contaminants. Co-precipitation in calcium carbonate is one attractive in-situ remediation strategy for divalent radionuclide and trace metal ions, such as ${ }^{60} \mathrm{Co},{ }^{137} \mathrm{Cs}$, and ${ }^{90} \mathrm{Sr}$. The reactions involved in this process are as follows [117].

(1) Enzymatically catalyzed urea hydrolysis produces $\mathrm{NH}_{4}^{+}$and 
$\mathrm{HCO}_{3}$ and raises $\mathrm{pH}$ :

$\mathrm{H}_{2} \mathrm{~N}(\mathrm{CO}) \mathrm{NH}_{2}+\mathrm{H}^{+}+2 \mathrm{H}_{2} \mathrm{O} \rightarrow 2 \mathrm{NH}_{4}^{+}+\mathrm{HCO}_{3}$

(2) $\mathrm{NH}_{4}^{+}$promotes desorption of cations $\mathrm{M}^{2+}$ (e.g. $\mathrm{Ca}^{2+}$ and $\mathrm{Sr}^{2+}$ ) from grain surfaces:

Solid- $\left(\mathrm{M}^{2+}\right)+2 \mathrm{NH}_{4}^{+} \Leftrightarrow$ Solid- $\left(\mathrm{NH}_{4}^{+}\right)_{2}+\mathrm{M}^{2+}$

(3) $\mathrm{HCO}_{3}$ promotes precipitation of calcium carbonate and coprecipitation of ${ }^{90} \mathrm{Sr}$ :

$$
\mathrm{x}^{90} \mathrm{Sr}^{2+}+(1-\mathrm{x}) \mathrm{Ca}^{2+}+2 \mathrm{HCO}_{3} \Leftrightarrow \mathrm{Ca}_{(1-\mathrm{x})}{ }^{90} \mathrm{Sr}_{\mathrm{x}} \mathrm{CO}_{3}+\mathrm{H}_{2} \mathrm{O}+\mathrm{CO}_{2}
$$
Sr:

The net reaction leads to produce carbonate minerals containing

Solid $-\left(\mathrm{x}^{90} \mathrm{Sr}^{2+}\right)+\mathrm{H}_{2} \mathrm{~N}(\mathrm{CO}) \mathrm{NH}_{2}{ }^{+}(1-\mathrm{x}) \mathrm{Ca}^{2+}+2 \mathrm{H}_{2} \mathrm{O} \rightarrow \mathrm{Ca} a_{(1-\mathrm{x})}$ $\mathrm{Sr}_{\mathrm{x}} \mathrm{CO}_{3}+$ Solid- $\left(\mathrm{NH}_{4}^{+}\right)_{2 \mathrm{x}}$

During calcite precipitation, heavy metal ions with ion radious close to $\mathrm{Ca}^{2+}$, such as $\mathrm{Sr}^{2+}, \mathrm{Pb}^{2+}, \mathrm{Cd}^{2+}$ and $\mathrm{Cu}^{2+}$ may be incorporated in to the $\mathrm{CaCO}_{3}$ crystal by substituting the $\mathrm{Ca}^{2+}$ in the lattice or entering the interstice or defect of crystal. Therefore, plant-derived urease induced $\mathrm{CaCO}_{3}$ precipitation can be used as a remediation technique in heavy metal removal.

\section{Conclusions}

This paper reviews intensively about the great potential of plantderived urease induced calcium carbonate precipitation as providing the way forward for the problems encountered in the field of geoenvironmental/geotechnical engineering as sustainable and ecofriendly manner. There are several potential applications of carbonate precipitation via plant-derived urease. Some of these applications are ground improvement by strength development of weak unconsolidated soil, removal of contaminants (e.g. radioactive pollutants) and calcium ions from groundwater and wastewaters, protection and restoration of limestone monuments and statuaries, plugging the pores of the oil-recover reservoir rock, stone formation (like sandstone), etc. The methodological summary and results of laboratory scale practices using plant-derived urease presented in this paper will have important implications for the design of technologies using plant-derived urease and to embark on the current research work as a possible alternative to the well-known bacterial approaches. In literature, there are limited amount of laboratory studies on plant-derived urease induced carbonate precipitation. More exploratory works at laboratory scale should be carried out to determine the effectiveness of the carbonate precipitation via plant-derived urease for industrial/ field applications. The major challenges in this novel area for field applications include assessment of subsurface soil condition including soil type, $\mathrm{pH}$, mineralogy and their interaction with the available fluids and minerals, ground water flow and available minerals. The optimal balance of substrates use for various applications should be studied to increase the economic feasibility and to reduce the production of unwanted byproducts (ex. ammonia production during hydrolysis of urea). Therefore, additional researches are also necessary to overcome these problems. It is necessary to investigate the durability, longevity and reversibility of the carbonate precipitation process under economical point of view. Furthermore, comparative studies should be done to check the feasibility of this method with that of the chemical methods which include environmental impacts as well as high cost. The potential of these bio minerals has brought a new revolution in various engineering applications but still there are some things to explore in order to bring this method environmentally safe, cost effective and to develop as a convenient technology from lab to field scales.

\section{References}

1. Karol RH (2003) Chemical grouting and soil stabilization. 3rd edn. M. Dekker, New York.

2. Gerilla GP, Teknomo K, Hokao K (2007) An environmental assessment of wood and steel reinforced.

3. Mora EP (2007) Life cycle, sustainability and the transcendent quality of building materials. Build Environ 42: 1329-1334.

4. DeJong JT, Soga KS, Kavazanjian E, Burns S, Van Paassen L, et al (2013) Biogeochemical processes and geotechnical applications: progress, opportunities, and challenges. Geotechnique 63: 287-301.

5. Mitchell JK, Santamarina JC (2005) Biological considerations in geotechnical engineering. J Geotech Geoenviron Eng 131: 1222-1233.

6. Castanier S, Le Metayer-Levrel G, Perthuisot JP (1999) Ca-carbonates precipitation and limestone genesis-the microbiogeologist point of view. Sediment Geol 126: 9-23.

7. De Muynck W, De Belie N, Verstraete W (2010a) Microbial carbonate precipitation in construction materials: A review. Ecological Eng 36: 118-136.

8. Khanafari A, Khams FN, Sepahy AA (2011) An investigation of biocement production from hard water. Middle-East J Scientific Res 7: 964-971.

9. Li M, Cheng X, Guo H (2013) Heavy metal removal by biomineralization of urease producing bacteria isolated from soil. Int Biodeterioration and Biodegradation 76: 81-85.

10. Prakash O, Talat M, Hasan SH, Pandey RK (2008) Enzymatic detection of heavy metal ions in aqueous solution from vegetable wastes by immobilizing pumpkin (Cucumis melo) urease in calcium alginate beads. Biotechnol and Bioprocess Eng 13: 210-216.

11. Dymond S (2004) Patent application PCT/AU2005/001927 (WO06066326), made by Murdoch University and calcite technology (pvt) Ltd. National phase filed in multiple countries.

12. Hammes F, Verstraete $\mathrm{W}$ (2002) Key roles of $\mathrm{pH}$ and calcium metabolism in microbial carbonate Precipitation. Revi Enviro Sci and Biotechnol 1: 3-7.

13. Das N, Kayastha AM, Srivastava PK (2002) Purification and characterization of urease from dehusked pigeonpea (Cajanus cajan L) seeds. Phytochemistry 61: 513-521

14. Polacco JC, Holland MA (1993) Roles of Urease in plant cells. Int Rev Cytol, 145: $65-103$

15. Hirayama C, Sugimura M, Saito H, Nakamura M (2000) Purification and properties of urease from the leaf of mulberry, (Morus alba). Phytochemistry 53: $325-330$

16. Blakely RL, Zerner B (1984) Jack bean urease: The first nickel enzyme. J Molecular Catalysis 23: 263-292.

17. Marzadori C, Miletti S, Gessa C, Ciurli S (1998) Immobilization of jack bean urease on hydroxyapatite: urease immobilization in alkaline soils. Soil Biol \& Biochem 30: 1485-1490.

18. Pettit NM, Smith ARJ, Freedman RB, Burns RG (1976) Soil urease: activity, stability, and kinetic properties. Soil Biol and Biochem 8: 479-484

19. Akiyama M, Kawasaki S, Aoi S (2011) Fundamental study on new grouting material using calcium phosphate compounds-Effect of addition of ammonia sources and soil microorganisms on unconfined compression strength. Japanese Geotechnical J 6: 513-524.

20. Rebata-Landa V, Santamarina JC (2006) Mechanical limits to microbial activity in deep sediments. Geochemistry, Geophysics, Geosystems 7: 1-12.

21. Van MA, van den Ham GA, Blauw M, Latil M, Benahmed N et al. (2011) Preventing internal erosion phenomena with the BioGrout process, in Proc. the 15th European Conference on Soil Mechanics and Geotechnical EngineeringGeotechnics of Hard Soils - Weak Rocks, 1079-1084.

22. Salwa M, Al-Thawadi (2013) Consolidation of Sand Particles by Aggregates of Calcite Nanoparticles Synthesized by Ureolytic Bacteria under Non-Sterile Conditions. J Chemical Sci Technol 2: 141-146.

23. Knorr B (2014) Enzyme-induced carbonate precipitation for the mitigation 
of fugitive dust. A thesis for the degree Master of Science, Arizona State University.

24. Nam IH, Chon CM, Jung KY, Choi SG, Choi H, et al. (2014) Calcite precipitation by ureolytic plant (Canavalia ensiformis) extracts as effective biomaterials. KSCE J Civil Eng (0000) 00: 1-6.

25. Hausinger RP (1993) Biochemistry of nickel, Plenum Press, New York, Chapter 3.

26. Holm L, Sander C (1997) An evolutionary treasure: unification of a broad set of amidohydrolases related to urease. Proteins 28: 72-82.

27. Follmer C (2008) Insights into the role and structure of plant ureases. Phytochemistry 69: 18-28.

28. Mobley HL, Island MD, Hausinger RP (1995) Molecular biology of microbial ureases. Microbiol Rev 59: 451-480.

29. Sirko A, Brodzik R (2000) Plant ureases: roles and regulation. Acta Biochim Pol 47: 1189-1195.

30. Andrews RK, Blakeley RL, Zerner B (1984) Urea and urease. Adv Inorg Biochem 6: 245-283.

31. Dixon NE, Gazzola TC, blakeley RL, Zermer B (1975) Letter: Jack bean urease (EC 3.5.1.5). A metalloenzyme. A simple biological role for nickel? J Am Chem Soc $97:$ : $4131-4133$.

32. Sumner JB (1926) The isolation and crystallization of the enzyme urease. J Biological Chemistry 69: 435-441.

33. Goring G, Fuchs E, Butler LG, Chopra SL, Hersh RT (1962) Some properties of urease. Biochemistry 1: 911-916.

34. Goring G, Chin CC (1965) Urease. IV. Its reaction with N-ethylmaleimide and with silver ion. Biochim Biophys Acta 99: 418-426.

35. Sumner JB (1951) Urease. In: The enzymes. Academic Press, New York: 1 873-892.

36. Frankenberger WT.jr., Tabatabai MA (1982) Amidase and urease activity in plants. Plant and soil 64 (2): 153-166.

37. Lai CM, Tabatabai MA (1992) Kinetic parameters of immobilized urease. Soil Biol Biochemistry 24: 225-228.

38. Boy d SA, Mortland MM (1985) Urease activity on a clay- organic complex. Soil Sci Soc Am J 49: 617-622.

39. Pervin MS, Jahan MGS, Masud Rana AYKMd, Sana NK, Rahman MH et al. (2013) Effects of some environmental variables on urease in germinating chickpea (Cicer arietinum L) seed. J Stress Physiol \& Biochemistry 9: 345-356.

40. Sung HY, Lee WM, Chiou MJ, Chang CT (1989) A procedure for purifying jack bean urease for clinical use. Proc Natl Sci Counc Repub China B 13: 250-257.

41. Srivastava PK, Kayastha AM, Srinivasan (2001) Characterization of gelatinimmobilized pigeonpea urease and preparation of a new urea biosensor. Biotechnol Appl Biochem 34: 55-62.

42. El-Shora HM (2001) Properties and immobilization of urease from leaves of Chenopodium album (C3). Botan Bull Acad Sinica 42: 251-258.

43. Singh R, Nye PH (1984) The effect of soil pH and high urea concentrations on urease activity in soil. J Soil Sci 35: 519-527.

44. Fidaleo M, Lavecchia R (2003) Kinetic Study of Enzymatic Urea Hydrolysis in the pH Range 4-9. Chem. Biochem Eng Q 17: 311-318.

45. Srivastava PK, Kayastha AM, Jagannadham MV (2002) Kinetics of inhibition and molecular asymmetry in pigeonpea (Cajanus cajan) urease. J Biochem Mol Biol Biophys 6: 1-6.

46. Krajewska B, Zaborska W, Chudy M (2004) Multi-step analysis of Hg2+ ion inhibition of jack bean urease. J Inorg Biochem 98: 1160-1168.

47. Zaborska W, Krajewska B, Olech Z (2004) Heavy metal ions inhibition of jack bean urease: potential for rapid contaminant probing. J Enzyme Inhib Med Chem 19: 65-69.

48. Du N, Chen M, Liu Z, Sheng L, Xu H, et al. (2012) Kinetics and mechanism of jack bean urease inhibition by $\mathrm{Hg}^{2+}$. Chem Cent $\mathrm{J}$ 6: 154

49. Wright Cl, Van-Buren L, Kroner Cl, Koning MM (2007) Herbal medicines as diuretics: a review of the scientific evidence. J Ethnopharmacol 114: 1-31.

50. Van Paassen LA, Ghose R, Van der Linden T, Van der Star W, Van Loosdrecht
M (2010) Quantifying biomediated ground improvement by ureolysis: largescale biogrout experiment. J Geotech Geoenv Eng 136: 1721-1728.

51. Martinez BC, DeJong JT (2009) Bio-mediated soil improvement: Load transfer mechanisms at the micro- and macro- scales. US China workshop on ground improvement technologies, ASCE-GSP 188: 242-251.

52. Mobley HL, Hausinger RP (1989) Microbial ureases: significance, regulation, and molecular characterization. Microbiol Rev 53: 85-108.

53. Wijngaarden WK, Vermolen FJ, Meurs GAM, Vuik, C (2012) A mathematical model and analytical solution for the fixation of bacteria in biopgrout. Transport in Porous Media 1-20.

54. Dharmakeerthi RS, Thenabadu MW (1996) Urease activity in soils: A Review. J Natn Sci Coun Sri Lanka 24: 159-195.

55. Palma RM, Conti MA (1990) Urease Activity in Argentine soils: Field studies and influence of sample treatment. Soil Biol Biochemistry 22: 105-108.

56. Reddy GB, Faza A, Bennet R. jr (1987) Activity of enzymes in rhyzosphere and non-rhyzosphere soils amended with sludge. Soil Biol Biochemistry 19 203-205.

57. Myers MG, McGarity JW (1968) The urease activity in profiles of five great soil groups from northern New South Walse. Plant and soil 28: 25-27.

58. Tabatabai MA (1977) Effects of trace elements in urease activity in soils. Soil Biology and Biochemistry $9: 9-13$

59. Skujins JJ (1967) Enzymes in soil. In: Soil Biochemistry. Vol.1 (Eds. E.D. McLaren and Pterson GH). Marcel Dekker, NewYork. 314-371.

60. Kumar V, Wagenet RJ (1984) Urease and kinetics of urea transformation in soils. Soil Sci 137: 263-269.

61. Zantua MI, Bremner JM (1977) Stability of Urease in Soils. Soil Biol Biochemistry 9: $135-140$.

62. Sahrawat KL (1984) Effect of temperature and moisture on urease activity in semi-arid tropical soils. Plant and soil 78: 401-408.

63. Paulsan KN, Kurtz LT (1970) Michaelis constant of soil urease. Soil Sci Soc Am P 34: 70-72.

64. Bremner JM, Mulvaney RL (1978) Urease Activity in soils. In: soil enzymes (Ed. R.G. Burns) Academic press, New York : 149-196.

65. Reithal FL (1971) Ureases. In: The enzymes. Vol. 4 (Ed. P.D. Boyer), Academic Press, New York. 1-21.

66. Fenn LB, Kissel DE (1973) Ammonia volatilization from surface application of ammonium compounds of calcareous soils: I. General theory. Soil Science Society of America Proceedings 37: 855-859.

67. Gould WD, Hagedorn C McCready RGL (1986) Urea transformations and fertilizer efficiency in soil. Advances in Agronomy 27: 25-87.

68. Witte CP, Medina-Escobar N (2001) In-gel detection of urease with nitroblue tetrazolium and quantification of the enzyme from different crop plants using the indophenol reaction. Anal Biochem 290: 102-107.

69. Kaltwasser H, Schlegel HG (1966) NADH-Dependent coupled enzyme assay for urease and other ammonia-producing systems. Anal Biochem 16: 132-138.

70. Croston CB, Smith AK, Cowan JC (1955) Measurement of urease activity in soybean oil meal. J Am Oil Chemists' Soc 32: 279-282.

71. Whiffin VS (2004) Microbial $\mathrm{CaCO} 3$ precipitation for the production of biocement, PhD Thesis, School of Biological Science and Biotechnology, Murdoch University, Australia.

72. Dilrukshi RAN, Watanabe J, Kawasaki S (2015) Sand Cementation Test using Plant-Derived Urease and Calcium Phosphate Compound. Materials Transactions 56: 1565-1572.

73. Banerjee S, Aggarwal A (2013) Enzymology, Immobilization and Applications of Urease Enzyme. Int Res J Biological Sci 2: 51-56.

74. http://www.agriinfo.in/default.aspx?page=topic\&superid=4\&topicid=1583

75. Smidsrod O, Skjak-Braek G (1990) Alginate as immobilization matrix for cells. Trends Biotechnol 8: 71-78.

76. Banerjee S, Debnath M (2006) Improvement strategy for operational stability of penicillin acylase for 6- APA production. Indian J Microbiol 46: 237-242.

77. Krajewska B (2009a) Ureases II Properties and their customizing by enzyme 
immobilizations: A review. J Molecular Catalysis B Enzymatic 59: 22-40.

78. DeJong JT, Mortense BM, Martinez BC, Nelson DC (2010) Biomediated soil improvement. Ecol Eng 36: 197-210.

79. Ferris FG, Setehmeir LG (1992) Bacteriogenic mineral plugging. United States Patent 664769 .

80. Gollapudi UK, Knutson CL, Bang SS, Islam MR (1995) A new method for controlling leaching through permeable channels. Chemosphere 30: 695-705.

81. Nemati M, Voordouw G (2005) Permeability profile modification using bacterially formed calcium carbonate: comparison with enzymic option. Proc Biochem 40: 925-933.

82. Kile DE, Eberl DD, Hoch AR, Reddy MM (2000) An assessment of calcite crystal growth mechanisms based on crystal size distributions. Geochem Cosmochim Acta 64: 2937-2950.

83. Castanier S, Le Metayer-Levrel G, Perthuisot JP (1999) Ca-carbonates precipitation and limestone genesis-the microbiogeologist point of view. Sediment Geol 126: 9-23.

84. Rivadeneyra MA, Párraga J, Delgado R, Ramos-Cormenzana A, Delgado G (2004) Biomineralization of carbonates by Halobacillus trueperi in solid and liquid media with different salinities. FEMS Microbiol Ecol 48: 39-46.

85. De Muynck W, Verbeken K, De Belie N, Verstraete W (2010b) Influence of urea and calcium dosage on the effectiveness of bacterially induced carbonate precipitation on limestone. Ecological Eng 36: 99-111.

86. Maier C, Hegeman J, Weinbauer MG, Gattuso Jean-Pierre (2009) Calcification of the cold-water coral Lophelia pertusa under ambient and reduced $\mathrm{pH}$. Biogeosci 6: 1671-1680.

87. Mortensen BM, Haber MJ, DeJong JT, Caslake LF, Nelson DC (2011) Effects of environmental factors on microbial induced calcium carbonate precipitation. J Appl Microbiol 111: 338-349.

88. Moore CH (2001) Carbonate reservoirs, porosity evolution and a diagenesis in a sequence stratigraphic framework. Elsevier, 444.

89. Folk RL (1974) The natural history of crystalline calcium carbonate: effect of magnesium content and salinity. J sedimentary petrol 44: 40-53

90. Fukue M, Fujimori Y, Kato Y, Nakagawa T, Mulligan CN (2010) Evidence of the production and dissolution of carbonate phases in bentonite formations. Applied clay sci 47: 133-138.

91. Fukue M, Ono Shin-Ichi, Sato Y (2011) Cementation of sands due to microbiologically- induced carbonate precipitation. Soils and foundations 51 : 83-93.

92. Ismail MA, Joer HA, Randolph MF, Meritt A (2002) Cementation of porous materials using calcite. Geotechnique 52: 313-324.

93. Somasundaran P, Agar GE (1967) The zero point of charge of calcite. J Colloid Interface Sci 24: 142-147.

94. Lippmann F (1973) Sedimentary carbonate minerals. Springer Verlag, New York, 228.

95. Rieger J, Frechen T, Cox G, Heckmann W, Schmidt C et al. (2007) Precursor structures in the crystallization/ precipitation processes of $\mathrm{CaCO}_{3}$ and control of particle formation by polyelectrolytes. Farad Discuss 136: 265-277.

96. Gower LB (2008) Biomimetic model systems for investigating the amorphous precursor pathway and its role in biomineralization. Chem Rev 108: 4551-4627.

97. Gebauer D, Gunawidjaja PN, Ko JY, Bacsik Z, Aziz B, et al. (2010) Protocalcite and proto-vaterite in amorphous calcium carbonates. Angew Chem Int Ed Engl 49: 8889-8891.

98. Rodriguez-Navarro C, Rodriguez-Gallego M, Ben Chekroun K, GonzalezMuñoz MT (2003) Conservation of ornamental stone by Myxococcus xanthusinduced carbonate biomineralization. Appl Environ Microbiol 69: 2182-2193.

99. Park SS, Choi SG, Nam IH (2014) Effect of plant induced calcite precipitation on the strength of sand. J Mater Civ Eng 06014017: 1-5.

100. Nemati M, Voordouw G (2003) Modification of porous media permeability, using calcium carbonate produced enzymatically in situ. Enzyme Microbial Technol 33: 635-642.

101. Bull M (2014) Bio inspired cementation of soil using plant enzyme. The thesis, Barrett, The Honors College at Arizona State University.
102. Neupane D, Yasuhara H, Kinoshita N, Unno T (2013) Applicability of enzymatic calcium carbonate precipitation as a soil-strengthening technique. J Geotechnical Geoenviron Eng 139: 2201-2211.

103. Hamdan N, Kavazanjian Jr E, O'Donnell S (2013) Carbonate cementation via plant derived urease. Proceedings of the 18th International Conference on Soil Mechanics and Geotechnical Engineering, Paris.

104. Yasuhara H, Neupane D, Hayashi K, Okamura M (2012) Experiments and predictions of physical properties of sand cemented by enzymatically-induced carbonate precipitation. The Japanese Geotechnical Soc Soils Foundations 52: 539-549.

105. Neupane D, Yasuhara H,Kinoshita N (2014) Optimization of treatment area of enzyme mediated calcite cementation: A novel soil improvement technique. 4th international conference on geotechnique, construction materials and environment, Brisbane, Australia.

106. Yamazaki H, Maeda K, Takahashi K, Zen K, Hayashi K (1998) Development of counter-measure against liquefaction by using solution type grout. Tech Note of Port Harbour Res Inst 905, 29 (in Japanese).

107.Tung MS (1998) Calcium phosphates: structure, composition, solubility and stability. In: Zahid, A.(Ed.), Calcium phosphates in biological and industrial systems. Kluwer Academic Publishers, Norwell, 1-19.

108. Chow LC (1991) Development of self-setting calcium phosphate cements. The Centennial Memorial Issue of the Ceramic Soc Japan 99: 954-964.

109. Ginebra MP, Fernández E, De Maeyer EA, Verbeeck RM, Boltong MG, et al (1997) Setting reaction and hardening of an apatitic calcium phosphate cement. J Dent Res 76: 905-912.

110. Dorozhkin SV, Epple M (2002) Biological and medical significance of calcium phosphates. Angew Chem Int Ed Engl 41: 3130-3146.

111. Akiyama M, Kawasaki S (2012a) Novel grout material using calcium phosphate compounds: In vitro evaluation of crystal precipitation and strength reinforcement. Eng Geol 125: 119-128.

112. Akiyama M, Kawasaki S (2012b) Microbialy mediated sand solidification using calcium phosphate compounds. Eng Geol 137-138: 29-39.

113. Dhami NK, Reddy MS, Mukherjee A (2013) Biomineralization of calcium carbonates and their engineered applications: a review. Front Microbiol 4: 314.

114. http://www.hardwater.org/water treatment.html

115. Hammes F, Seka A, de Knijf S, Verstraete W (2003) A novel approach to calcium removal from calcium-rich industrial wastewater. Water Res 37: 699-704.

116. Jroundi F, Fernandez-Vivas A, Rodriguez-Navarro C, Bedmar EJ, GonzalezMu noz MT (2010) Bioconservation of deteriorated monumental calcarenite stone and identification of bacteria with carbonatogenic activity. Environ Microbiol 60: 39-54

117. Wu Y, Franklin JBA, Spycher N, Hubbard SS, Zhang G, et al. (2011) Geophysical monitoring and reactive transport modeling of ureolytically-driven calcium carbonate precipitation. Geochemical Transactions 12: 7.

118. Hamzah NA (2014) Main properties of urease partially purified from seeds of Syrian mesquite (Prosopis farcta). J Babylon University Pure and Applied Sci 22: 1071-1079.

119. Krajewska B (2009b) Ureases I. Functional, catalytic and kinetic properties: A review. J Mol Catal B -Enz, 59: 9-21.

120. Watanabe $Y$, Sarumaru H, Shimada N (1983) Distribution of urease in the higher plants, Chiba University Faculty of Horticulture Report 32: 37-43.

121. Smith AK, Belter PA, Anderson RL (1956) Urease Activity in Soybean Meal Products. The J Am Oil Chemists' Soc XXXIII: 360-363.

122.http://www.sigmaaldrich.com/technical-documents/protocols/biology/ enzymatic-assay-of-urease-from-jack-beans.html

123.https://www.sigmaaldrich.com/content/dam/sigmaaldrich/docs/Sigma/ General_Information/2/urease.pdf

124. Caskey CD Jr, Knapp HC (1944) Method for detecting inadequately heated Soybean oil meal. Ind Eng Chem Anal ED 16: 40.

125. Bird HR, Boucher RO, Caskey CD Jr, Hayward JW, Hunter JE (1947) Resistance of the Echinococcus granulosus cyst wall to complement activation: analysis of the role of InsP6 deposits. J Asso Official Agr Chern 30: 354-364. 
Citation: Dilrukshi RAN, Kawasaki S (2016) Effective Use of Plant-Derived Urease in the Field of Geoenvironmental/Geotechnical Engineering. J Civil Environ Eng 6: 207. doi:10.4172/2165-784X.1000207

Page 13 of 13

126. http://www.scribd.com/doc/220182129/Actividad-Ureasica-22-90

127.http://www.fao.org/docrep/field/003/ab479e/AB479E05.htm

128. Schramm G, Aines PD (1959) Colorimetric determination of urease activity in soybean meals. J Am Oil Chemists' Soc 36: 1-3.

129. http://www.scienceinschool.org/print/607

130.http://www.eurovolvox.org/Private/Meetings/Napoli/Urease

131. Khan M, Javed MM, Zahoor S, Ikram-UI-Haq (2013) Kinetics and thermodynamic study of urease extracted from soybeans. Biologia (Pakistan), 59: 7-14.

132. Selvamurugan C, Lavanya A, Sivasankar B (2007) A comparative study on immobilization of urease on different metrices. J scientific industrial res 66 : 655-659.
133. Kandeler E, Gerber $\mathrm{H}$ (1988) Short-term assay of soil urease activity using colorimetric etermination of ammonium. Biology and Fertility of Soils 6: 68-72.

134. Allison S (2001) Urease Protocol.

135. Danjo T, Kawasaki S (2014) Formation mechanisms of beach rocks in Okinawa and Ishikawa, Japan, with a focus on cements. Materials Transactions 55 493-500.

136. Christensen WB (1946) Urea Decomposition as a Means of Differentiating Proteus and Paracolon Cultures from Each Other and from Salmonella and Shigella Types. J Bacteriol 52: 461-466.

137. Okyay TO, Frigi Rodrigues D (2013) High throughput colorimetric assay for rapid urease activity quantification. J Microbiol Methods 95: 324-326. 